\title{
Prediction of enteric methane output from milk fatty acid concentrations and rumen fermentation parameters in dairy cows fed sunflower, flax, or canola seeds
}

\author{
R. Mohammed, S. M. McGinn, and K. A. Beauchemin ${ }^{1}$ \\ Agriculture and Agri-Food Canada, Lethbridge Research Centre, Lethbridge, Alberta T1J 4B1, Canada
}

\begin{abstract}
Milk fatty acid (FA) composition has been suggested as a means of predicting enteric methane $\left(\mathrm{CH}_{4}\right)$ output in lactating dairy cattle because of the common biochemical pathways among $\mathrm{CH}_{4}$, acetate, and butyrate in the rumen. Sixteen lactating Holstein cows were used in a Latin square design with four 28-d periods. All diets contained steam-rolled barley, a pelleted supplement, barley silage [45\% of dietary dry matter (DM)] and 3.3\% added fat (DM basis) from 1 of 4 sources: calcium salts of long-chain FA (palm oil; control) or crushed oilseeds from sunflower, flax, or canola. The objectives of this study were to (1) compare the effect of diets on milk FA profile; (2) model $\mathrm{CH}_{4}$ production from milk FA composition, intake, and rumen fermentation variables; and (3) test the applicability of $\mathrm{CH}_{4}$ prediction equations reported in previous studies. Methane $(\mathrm{g} / \mathrm{d})$ was measured in chambers (2 animals/chamber) on 3 consecutive days (d 21-23). The test variables included total DM intake (DMI, $\mathrm{kg} / \mathrm{d}$; d 21-23), forage DMI $(\mathrm{kg} / \mathrm{d}$; d 21-23), milk yield ( $\mathrm{kg} / \mathrm{d} ; \mathrm{d} 21-23)$, milk components (d 18-21), milk FA composition (\% total FA methyl esters; d 18-21), rumen volatile FA (mol/100 mol; d 19-21), and protozoal counts (d 19-21), and were averaged by chamber and period to determine relationships between $\mathrm{CH}_{4}$ and the test variables. Milk trans $(t) 10-$, $t 11-18: 1$, and $\operatorname{cis}(c) 9 t 11-18: 2$ were greater for sunflower seeds compared with the other diets. Forage DMI (correlation coefficient, $\mathrm{r}=0.52 ; \mathrm{n}=32)$, DMI $(\mathrm{r}=0.52$; $\mathrm{n}=32$ ), and rumen acetate + butyrate:propionate $(\mathrm{r}$ $=0.72 ; \mathrm{n}=16)$ were positively related to $\mathrm{CH}_{4}(\mathrm{~g} / \mathrm{d})$, whereas rumen propionate $(\mathrm{r}=0.63 ; \mathrm{n}=16)$, milk $c 9-17: 1(\mathrm{r}=0.64 ; \mathrm{n}=32)$, and $c 11-18: 1(\mathrm{r}=0.64 ; \mathrm{n}$ $=32$ ) were negatively related to $\mathrm{CH}_{4}$. The best regression equation (coefficient of determination $=0.90 ; \mathrm{n}$ $=16)$ was $\mathrm{CH}_{4}(\mathrm{~g} / \mathrm{d})=-910.8( \pm 156.7) \times$ milk $c 9$ $17: 1+331.2( \pm 88.8) \times$ milk 16:0 iso $+0.0001( \pm 0.00)$ $\times$ total entodiniomorphs $+242.5( \pm 39.7)$. Removing
\end{abstract}

Received March 16, 2011.

Accepted August 8, 2011.

${ }^{1}$ Corresponding author: karen.beauchemin@agr.gc.ca rumen parameters from the model also resulted in a reasonably good estimate (coefficient of determination $=0.83 ; \mathrm{n}=32$ ) of $\mathrm{CH}_{4}$. Stepwise regression analysis within diets resulted in greater coefficient of determination and lower standard error values. Predictions of $\mathrm{CH}_{4}$, using equations from previous studies for the data set from this study, resulted in a mean overestimation ranging from 19 to $61 \%$ across studies. Thus, milk FA alone may not be suitable for developing universal $\mathrm{CH}_{4}$ prediction equations.

Key words: methane, milk fatty acid composition, prediction equation

\section{INTRODUCTION}

Enteric methane $\left(\mathrm{CH}_{4}\right)$ produced by ruminants represents an energy loss to the animal (Johnson and Johnson, 1995). It also contributes to the enhanced greenhouse gas effect and global warming (IPCC, 2006). A need exists for simple, inexpensive measurement techniques to estimate $\mathrm{CH}_{4}$ emissions from dairy cows in research settings and under field conditions. Current measurement techniques, such as whole-animal chambers and tracer gas techniques, require complex instrumentation and, thus, are limited in their use (Johnson and Johnson, 1995).

Decades ago, a stoichiometric relationship between $\mathrm{CH}_{4}$ and ruminal acetate, propionate, and butyrate was proposed (Demeyer and Van Nevel, 1975). These shortchain fatty acids (FA) formed in the rumen in particular act as precursors for the de novo synthesis of milk FA in the mammary tissue. Because the precursors for the synthesis of $\mathrm{CH}_{4}$ and de novo synthesis of milk FA arise in the rumen, a relationship between $\mathrm{CH}_{4}$ and milk FA was proposed (Chilliard et al., 2009). Chilliard et al. (2009) developed $\mathrm{CH}_{4}$ predictive equations from milk FA composition in dairy cows offered 3 different physical forms of linseed (crude, extruded, and linseed oil). Their best equation predicted $\mathrm{CH}_{4}\left(\mathrm{R}^{2}=0.95\right)$ with the milk FA 16:0, $\operatorname{trans}(\boldsymbol{t}) 16 / \operatorname{cis}(\boldsymbol{c}) 14-18: 1, \quad c 9-$ 14:1, 18:2n-6, and forage intake. More recently, Dijkstra et al. (2011) developed $\mathrm{CH}_{4}$ predictive equations from 
milk FA using a data set containing 50 observations from 3 different experiments. However, their best equation contained a different set of variables (17:0 anteiso, $t 10+t 11-18: 1, c 11-18: 1$, and $c 13-18: 1)$ with a coefficient of determination $\left(\mathrm{R}^{2}\right)$ value of 0.73 . Yet another study (Montoya et al., 2011) reported that milk odd- and branched-chain fatty acids (OBCFA) hold potential as predictors of rumen methanogenesis. In the above studies, the variables contributing to $\mathrm{CH}_{4}$ were not the same, suggesting that the applicability of these equations across varied feeding conditions may be limited.

In a previous study, Beauchemin et al. (2009) investigated the effect of crushed sunflower seed (SS), canola seed (CS), flax seed (FS), and a control diet [CTL; calcium salts of long-chain FA (palm oil)] on $\mathrm{CH}_{4}$ emissions. They found that the oilseed-supplemented diets decreased $\mathrm{CH}_{4}$ production $(\mathrm{g} / \mathrm{d})$ by an average of $13 \%$ compared with the CTL. The various sources of long-chain FA used in their study differed in degree of saturation and rumen availability and, hence, provided an opportunity to compare their effects on milk FA composition and evaluate the potential of predicting $\mathrm{CH}_{4}$ production within and across diets. Thus, the objectives of the present study were to expand the study presented by Beauchemin et al. (2009) to (1) determine the effects of CTL, SS, FS, and CS diets on milk FA profile; (2) model the relationship between $\mathrm{CH}_{4}$ production and milk FA concentrations, intake, milk production, and rumen fermentation variables; and (3) test the $\mathrm{CH}_{4}$ prediction equations reported by Chilliard et al. (2009) and Dijkstra et al. (2011).

\section{MATERIALS AND METHODS}

\section{Experimental Design}

Experimental details were reported in a companion paper (Beauchemin et al., 2009). In brief, 16 lactating Holstein cows maintained in 2 groups ( 8 primiparous ruminally cannulated and 8 multiparous intact cows) were offered 4 diets in four 28 -d periods in a Latin square design. The experimental diets were SS, FS, CS, and CTL. Dietary forage:concentrate ratio was 45:54, with barley silage as the sole forage component. All diets contained steam-rolled barley $(\sim 32.5 \%$ DM basis $)$ and a pelleted supplement containing ground barley, protein sources, vitamins, and minerals. Oilseeds were crushed in a roller mill to ensure the hulls were cracked and added to the diets to provide $3.3 \%$ added fat on a DM basis. Detailed ingredients and chemical composition of the diets are reported in Table 1.

Dry matter intakes and milk production (a.m. and p.m.) were recorded daily throughout the experiment. However, for this study, only DMI and milk produced while the animals were in the chamber (d 21-23) were considered. Total lipids from the TMR were extracted with chloroform:methanol (1:1) along with an internal standard (23:0; Mohammed et al., 2009). The TMR fat was methylated with methanolic $\mathrm{HCl}$ and the total dietary FA content was determined relative to the response factors for a known amount of the internal standard (23:0). The total FA intake was determined as the product of DMI and the total FA content of the diet. Intakes of individual FA for each cow were determined by multiplying the proportion of the particular FA with the total FA consumed.

Milk sampled (a.m. and p.m.) on 3 consecutive days (d 18-20) was used for component analysis (reported in Beauchemin et al., 2009). Milk FA composition was determined from the pooled milk samples (d 18-20) as described by Mohammed et al. (2009). In brief, milk fat was extracted using a chloroform:methanol:water (2:2:1.8) mixture and methylated with $0.5 \mathrm{~N}$ methanolic base (Supelco Inc., Bellefonte, PA). The FA methyl esters (FAME) were analyzed on a Varian 3600 gas chromatograph (Varian Chromatography Systems, Walnut Creek, CA) with a temperature-programmable on-column injector and flame ionization detector using the $175^{\circ} \mathrm{C}$ temperature program described by Kramer et al. (2008). Injector and detector temperatures were maintained at $250^{\circ} \mathrm{C}$ and helium was used as the carrier gas at a flow rate of $1 \mathrm{~mL} / \mathrm{min}$. The FAME were identified by comparison with the standards GLC 463 and UC-59M (both from Nu-Chek prep Inc., Elysian, $\mathrm{MN})$. Individual FAME were reported as a percentage of total FAME. The short-chain FAME were corrected for their flame ionization detector deficiency based on theoretical correction factors reported by Wolff et al. (1995).

Ruminal contents were collected only from primiparous cows at 0 and $4 \mathrm{~h}$ after the morning feeding on $\mathrm{d}$ 19 to 21. Rumen fermentation parameters ( $\mathrm{pH}, \mathrm{VFA}$, and $\left.\mathrm{NH}_{3}-\mathrm{N}\right)$ were analyzed before $(0 \mathrm{~h})$ and after $(4 \mathrm{~h})$ feeding, whereas protozoal counts were determined in the samples after feeding as described by Beauchemin et al. (2009). Readers are referred to Beauchemin et al. (2009) for the effect of diets on rumen fermentation variables.

Enteric $\mathrm{CH}_{4}$ was measured in environmental chambers (2 animals/chamber) on 3 consecutive days in the last week of each period (d 21-23). Cows fed the same diet were paired and housed in each chamber in 2 individual stanchions equipped with feeders. The detailed procedure for recording $\mathrm{CH}_{4}$ in the chambers was described in Beauchemin et al. (2007, 2009). In brief, cows were conditioned to the chambers before the start of the experiment. Chambers were calibrated at the beginning of each period by releasing a known amount of 
Table 1. Ingredient and chemical composition of the $\operatorname{diets}^{1}$ (DM basis; Beauchemin et al., 2009)

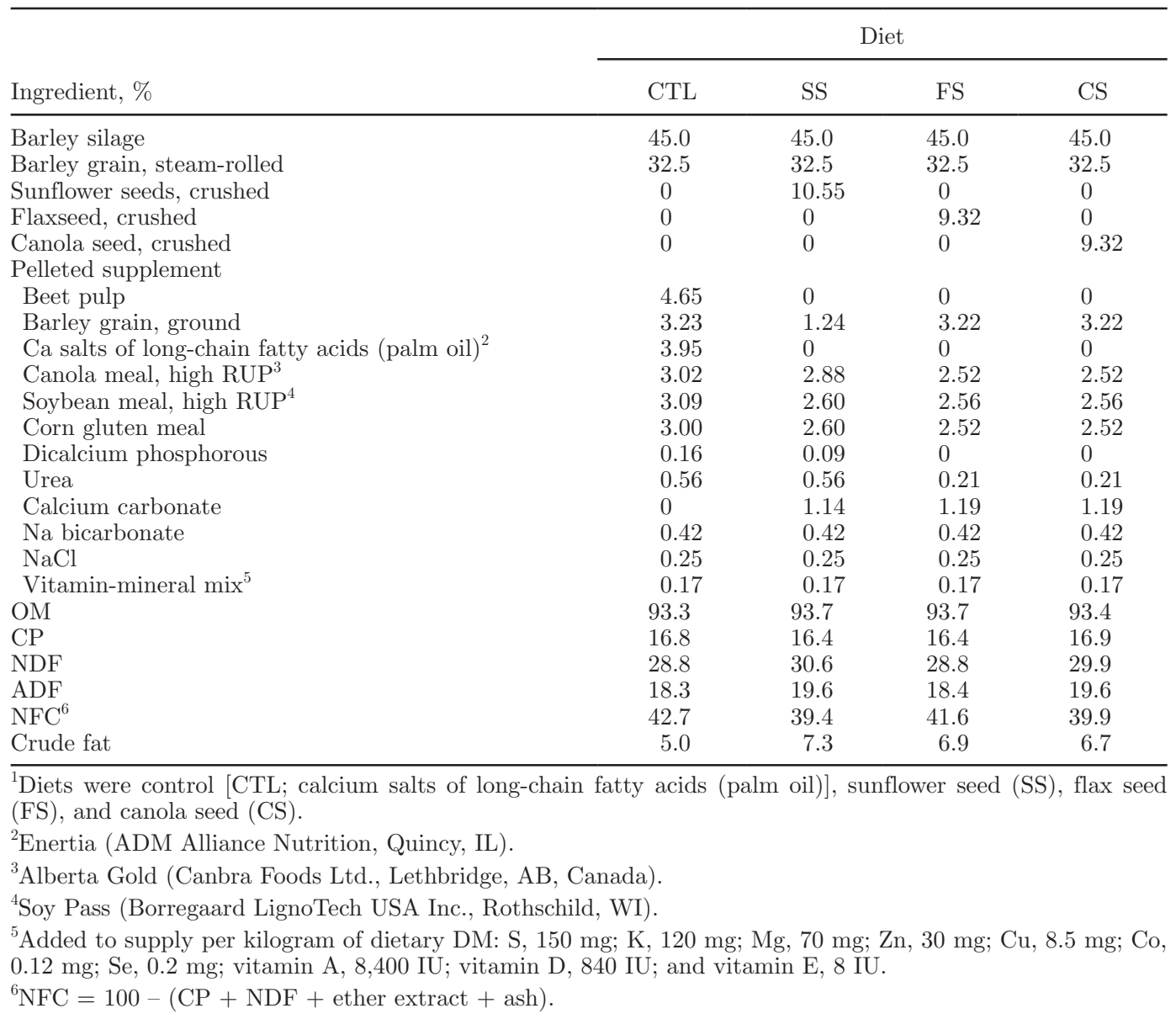

$\mathrm{CH}_{4}$ gas, and the measuring procedures were adjusted to obtain $100 \%$ recovery. Air flow rates in the intake and exhaust ducts were measured and $\mathrm{CH}_{4}$ concentrations in these ducts were monitored (Beauchemin et al., 2007). The amount of $\mathrm{CH}_{4}$ produced within a chamber by the 2 cows was determined by calculating the difference between the incoming and outgoing mass of $\mathrm{CH}_{4}$.

\section{Statistical Analysis}

The milk FAME and intake of FA were analyzed by the Mixed procedure of SAS (version 9.1; SAS Institute Inc., Cary, NC) using data from individual cows ( $\mathrm{n}=$ 64). Cow within diet was the experimental unit, with diet designated as fixed factor and cow and period as random factors. For all correlations and stepwise regression analyses, intake (total DMI, $\mathrm{kg} / \mathrm{d}$; forage DMI, $\mathrm{kg} / \mathrm{d}$; FA intake, g/d) and milk production (milk yield, $\mathrm{kg} / \mathrm{d}$; milk components, percentage and $\mathrm{kg} / \mathrm{d}$ ) parameters, rumen fermentation parameters (VFA, mol/100 mol; pH; protozoal counts), milk FA composition (\% of total FAME) and $\mathrm{CH}_{4}(\mathrm{~g} / \mathrm{d})$ were averaged by chamber (experimental unit) and period before including them in the model. It should be noted that milk FA variables $\leq 0.02 \%$ [13:0 iso; $21: 0 ; t 5$ - and $t 10-16: 1 ; c 7$ $17: 1 ; c 9-$ and $c 10-16: 1 ; t 4-$ and $t 5-18: 1 ; t 6 / t 11-, t 12-$, and $t 13-20: 1 ; c 13-$ and $c 15-22: 1 ; t 9, t 12-18: 2 ; 18: 3 n-6$; 20:2n-6; 22:2n-6; EPA; DHA; and conjugated linoleic acid (CLA) isomers such as $t 9, c 11-, c 10, c 12-, c 11, c 13-$, $t 12, t 14-$, and $t 11, t 13-\mathrm{CLA})]$ were not included in the regression analysis. Correlations between $\mathrm{CH}_{4}$ and the test variables (intake, milk production, rumen fermentation, and milk FA composition) were determined using the PROC CORR procedure of SAS. Stepwise regression analysis (PROC STEPWISE procedure of SAS) was done using $\mathrm{CH}_{4}(\mathrm{~g} / \mathrm{d})$ as the dependent variable and the test variables as independent variables using a threshold of $P<0.05$. Correlations and stepwise regression analyses were done using data from all diets $(\mathrm{n}=32$ for intake variables and milk FA profile; $\mathrm{n}=16$ for rumen parameters) as well as within diets ( $\mathrm{n}=8$ for intake variables and milk FA profile; $\mathrm{n}=4$ for rumen parameters). 


\section{RESULTS}

\section{Intakes}

Dry matter intakes were greater for the CS diet compared with the SS, FS, and CTL diets (Table 2). Intakes of 12:0, 14:0, 16:0, and saturated fatty acids (SFA) were greater for the CTL diet compared with the oilseed-supplemented diets. Intake of oleic acid was greatest for the CS diet, followed by the CTL, FS, and SS diets, with no difference between the latter 2. Linoleic acid (LeA) intake was greatest for the SS diet and linolenic acid $(\mathbf{L N})$ intake was greatest for the FS diet. However, intake of LeA + LN was greatest for the FS diet, followed by the SS, CS and CTL diets.

\section{Milk FA Composition}

Total milk SFA were greater for the CTL diet compared with other diets (Table 3). Milk 16:0 was greater for the CTL diet compared with the other diets. Among the $t-18: 1$ isomers, $t 10$ - and $t 11-18: 1$ concentrations were greater for the SS diet compared with the CS, FS, and CTL diets (Table 4). Consistent with this finding, total $t-18: 1$ and total $t$-monounsaturated FA were also greater for the SS diet compared with the CS, FS, and CTL diets. Milk $c 9 t 11-18: 2$ (rumenic acid, RA) content and yield were greater for the SS diet and least for the CTL diet, but lower for the FS and CS diets compared with the SS diet, with no difference between the two. However, milk t10,c12-CLA was not different among the diets. Among the 4 desaturase indices calculated, only $c 9-18: 1 / 18: 0$ differed among treatments with greater values observed for the CTL diet compared with other diets.

\section{Correlations Between $\mathrm{CH}_{4}$ and the Test Variables}

The significant positive and negative correlations between $\mathrm{CH}_{4}$ and the test variables from all diets (n $=32$ for milk FA, intake and production variables; $\mathrm{n}=16$ for rumen variables) are reported in Table 5 . Among intake variables, $\mathrm{CH}_{4}$ was positively related to DMI and forage DMI ( $\mathrm{r}=0.52$ for both). Enteric $\mathrm{CH}_{4}$ was positively related to acetate + butyrate:propionate $(\mathrm{r}=0.72)$, acetate:propionate $(\mathrm{r}=0.66)$, and total entodiniomorphs $(\mathrm{r}=0.58)$, and negatively related to rumen propionate $(\mathrm{r}=0.63)$ and valerate $(\mathrm{r}=0.60)$ among the rumen variables. Correlations of $\mathrm{CH}_{4}$ with milk FA revealed that $\mathrm{CH}_{4}$ was negatively related to $c 9$ 17:1 $(\mathrm{r}=0.65)$ and $c 11-18: 1(\mathrm{r}=0.64)$ and positively related to total SFA $(\mathrm{r}=0.39)$. When correlations were repeated within diets $(\mathrm{n}=8$ for milk FA, intake and production variables and $n=4$ for rumen variables), the correlation coefficient values were greater (Table 6) compared with the correlations among diets (Table 5). For the flax diet, $\mathrm{CH}_{4}$ was strongly and positively related to rumen acetate, butyrate, and milk 14:0 iso and negatively related to milk $c 9-17: 1, c 11-18: 1$, and c13-18:1 (Table 6). The correlation coefficient values for the FS diet were relatively higher than for the other diets. Milk 9:0, $\Sigma$ 8:0 to14:0, and $\Sigma$ SFA were positively related and milk $c 9-17: 1$ was negatively related to $\mathrm{CH}_{4}$ for the SS diet. Enteric $\mathrm{CH}_{4}$ for the CTL diet was posi-

Table 2. Effect of $\operatorname{diets}^{1}$ on DMI, fatty acid intake, milk production, and methane emissions

\begin{tabular}{|c|c|c|c|c|c|c|}
\hline \multirow[b]{2}{*}{ Variable $^{2}$} & \multicolumn{4}{|c|}{ Diet } & \multirow[b]{2}{*}{ SEM } & \multirow[b]{2}{*}{$P$-value } \\
\hline & CTL & SS & FS & CS & & \\
\hline Total DMI, kg/d & $18.1^{\mathrm{b}}$ & $18.2^{\mathrm{b}}$ & $18.0^{\mathrm{b}}$ & $19.4^{\mathrm{a}}$ & 0.54 & 0.03 \\
\hline Forage DMI, $\mathrm{kg} / \mathrm{d}$ & 8.2 & 8.2 & 8.1 & 8.7 & 0.29 & 0.12 \\
\hline Milk yield, $\mathrm{kg} / \mathrm{d}$ & 27.0 & 26.1 & 25.7 & 26.4 & 1.77 & 0.76 \\
\hline Milk fat, $\%$ & 3.2 & 3.0 & 3.3 & 3.1 & 0.18 & 0.19 \\
\hline Milk fat, $\mathrm{kg} / \mathrm{d}$ & 0.84 & 0.77 & 0.81 & 0.80 & 0.06 & 0.38 \\
\hline Methane, $\mathrm{g} / \mathrm{d}$ & $293^{\mathrm{a}}$ & $264^{\mathrm{b}}$ & $241^{\mathrm{b}}$ & $265^{\mathrm{b}}$ & 19.3 & $<0.01$ \\
\hline Total FA intake, $\mathrm{g} / \mathrm{d}$ & $1,352^{\mathrm{b}}$ & $1,267^{\mathrm{b}}$ & $1,298^{\mathrm{b}}$ & $1,590^{\mathrm{a}}$ & 56.8 & $<0.01$ \\
\hline $12: 0$ & $5.07^{\mathrm{a}}$ & $0.73^{\mathrm{b}}$ & $0.61^{\mathrm{b}}$ & $0.83^{\mathrm{b}}$ & 0.22 & $<0.01$ \\
\hline 14:0 & $20.6^{\mathrm{a}}$ & $6.8^{\mathrm{b}}$ & $6.2^{\mathrm{b}}$ & $7.1^{\mathrm{b}}$ & 0.40 & $<0.01$ \\
\hline $16: 0$ & $635^{\mathrm{a}}$ & $201^{\mathrm{b}}$ & $191^{\mathrm{b}}$ & $191^{\mathrm{b}}$ & 12.8 & $<0.01$ \\
\hline $18: 0$ & $57.6^{\mathrm{a}}$ & $60.9^{\mathrm{a}}$ & $55.9^{\mathrm{a}}$ & $32.5^{\mathrm{b}}$ & 2.36 & $<0.01$ \\
\hline SFA & $803^{\mathrm{a}}$ & $352^{\mathrm{b}}$ & $317^{\mathrm{b}}$ & $323^{\mathrm{b}}$ & 16.9 & $<0.01$ \\
\hline Oleic acid & $273^{\mathrm{b}}$ & $226^{\mathrm{c}}$ & $231^{\mathrm{c}}$ & $614^{\mathrm{a}}$ & 16.7 & $<0.01$ \\
\hline LeA & $138^{\mathrm{d}}$ & $559^{\mathrm{a}}$ & $330^{\mathrm{c}}$ & $402^{\mathrm{b}}$ & 17.6 & $<0.01$ \\
\hline $\mathrm{LN}$ & $11.6^{\mathrm{c}}$ & $19.6^{\mathrm{c}}$ & $326^{\mathrm{a}}$ & $89.6^{\mathrm{b}}$ & 10.2 & $<0.01$ \\
\hline $\mathrm{LeA}+\mathrm{LN}$ & $150^{\mathrm{d}}$ & $579^{\mathrm{b}}$ & $656^{\mathrm{a}}$ & $491^{\mathrm{c}}$ & 24.8 & $<0.01$ \\
\hline
\end{tabular}

${ }^{\mathrm{a}-\mathrm{d}}$ Within a row, means bearing different superscript letters are significantly different $(P<0.05)$.

${ }^{1}$ Diets were control [CTL; calcium salts of long-chain fatty acids (palm oil)], sunflower seed (SS), flax seed (FS), and canola seed (CS).

${ }^{2} \mathrm{FA}=$ fatty acids $\mathrm{SFA}=$ saturated $\mathrm{FA} ; \mathrm{LeA}=$ linoleic acid $; \mathrm{LN}=$ linolenic acid. 
Table 3. Effect of diets ${ }^{1}$ on milk saturated fatty acid (SFA) composition

\begin{tabular}{|c|c|c|c|c|c|c|}
\hline \multirow[b]{2}{*}{ Variable $^{2}$} & \multicolumn{4}{|c|}{ Diet } & \multirow[b]{2}{*}{ SEM } & \multirow[b]{2}{*}{$P$-value } \\
\hline & CTL & SS & FS & CS & & \\
\hline 4:0 & 0.64 & 0.48 & 0.58 & 0.48 & 0.08 & NS \\
\hline $5: 0$ & 0.08 & 0.07 & 0.07 & 0.06 & 0.01 & NS \\
\hline $6: 0$ & 1.00 & 1.05 & 1.15 & 1.20 & 0.09 & 0.01 \\
\hline $7: 0$ & 0.20 & 0.18 & 0.16 & 0.17 & 0.02 & NS \\
\hline $8: 0$ & 0.77 & 0.83 & 0.91 & 0.93 & 0.06 & $<0.01$ \\
\hline 9:0 & 0.25 & 0.22 & 0.20 & 0.30 & 0.04 & NS \\
\hline 10:0 & 1.57 & 1.69 & 1.91 & 2.05 & 0.15 & $<0.01$ \\
\hline 11:0 & $0.28^{\mathrm{c}}$ & $0.30^{\mathrm{bc}}$ & $0.35^{\mathrm{ab}}$ & $0.37^{\mathrm{a}}$ & 0.03 & 0.01 \\
\hline $12: 0$ & $2.07^{\mathrm{b}}$ & $2.19^{\mathrm{b}}$ & $2.43^{\mathrm{a}}$ & $2.59^{\mathrm{a}}$ & 0.15 & $<0.01$ \\
\hline $13: 0$ & $0.08^{\mathrm{c}}$ & $0.10^{\mathrm{b}}$ & $0.12^{\mathrm{ab}}$ & $0.13^{\mathrm{a}}$ & 0.01 & $<0.01$ \\
\hline $14: 0$ iso & 0.12 & 0.14 & 0.12 & 0.11 & 0.02 & NS \\
\hline $14: 0$ & $8.59^{\mathrm{b}}$ & $8.65^{\mathrm{b}}$ & $8.88^{b}$ & $9.75^{\mathrm{a}}$ & 0.37 & $<0.01$ \\
\hline 15:0 iso & $0.11^{\mathrm{b}}$ & $0.13^{\mathrm{a}}$ & $0.13^{\mathrm{a}}$ & $0.13^{\mathrm{a}}$ & 0.01 & $<0.01$ \\
\hline 15:0 anteiso & $0.36^{\mathrm{b}}$ & $0.35^{\mathrm{b}}$ & $0.40^{\mathrm{a}}$ & $0.42^{\mathrm{a}}$ & 0.02 & $<0.01$ \\
\hline $15: 0$ & $0.86^{\mathrm{b}}$ & $0.86^{\mathrm{b}}$ & $0.91^{\mathrm{ab}}$ & $0.98^{\mathrm{a}}$ & 0.04 & $<0.01$ \\
\hline 16:0 iso & 0.22 & 0.24 & 0.26 & 0.21 & 0.03 & NS \\
\hline $16: 0$ & $36.18^{\mathrm{a}}$ & $22.33^{\mathrm{b}}$ & $22.62^{\mathrm{b}}$ & $22.76^{\mathrm{b}}$ & 0.76 & $<0.01$ \\
\hline $17: 0$ & $0.35^{\mathrm{b}}$ & $0.36^{\mathrm{b}}$ & $0.43^{\mathrm{a}}$ & $0.41^{\mathrm{a}}$ & 0.02 & $<0.01$ \\
\hline 17:0 anteiso & $0.34^{\mathrm{a}}$ & $0.27^{\mathrm{b}}$ & $0.36^{\mathrm{a}}$ & $0.34^{\mathrm{a}}$ & 0.02 & $<0.01$ \\
\hline 18:0 iso & 0.03 & 0.03 & 0.04 & 0.03 & 0.00 & NS \\
\hline $18: 0$ & $8.76^{\mathrm{b}}$ & $14.32^{\mathrm{a}}$ & $13.54^{\mathrm{a}}$ & $13.94^{\mathrm{a}}$ & 0.73 & $<0.01$ \\
\hline 20:0 & $0.10^{\mathrm{b}}$ & $0.12^{\mathrm{b}}$ & $0.10^{\mathrm{b}}$ & $0.21^{\mathrm{a}}$ & 0.01 & $<0.01$ \\
\hline $24: 0$ & $0.02^{\mathrm{b}}$ & $0.02^{\mathrm{b}}$ & $0.03^{\mathrm{a}}$ & $0.02^{\mathrm{b}}$ & 0.00 & $<0.01$ \\
\hline SFA & $62.82^{\mathrm{a}}$ & $54.90^{\mathrm{c}}$ & $55.53^{\mathrm{c}}$ & $57.53^{\mathrm{b}}$ & 1.14 & $<0.01$ \\
\hline Iso FA & 0.69 & 0.77 & 0.72 & 0.70 & 0.05 & NS \\
\hline Anteiso FA & $0.75^{\mathrm{b}}$ & $0.68^{\mathrm{c}}$ & $0.82^{\mathrm{a}}$ & $0.83^{\mathrm{a}}$ & 0.04 & $<0.01$ \\
\hline Branched FA & 1.45 & 1.45 & 1.54 & 1.52 & 0.07 & NS \\
\hline
\end{tabular}

${ }^{\mathrm{a}-\mathrm{c}}$ Within a row, means bearing different superscript letters are different $(P<0.05)$.

${ }^{1}$ Diets were control [CTL; calcium salts of long-chain fatty acids (palm oil)], sunflower seed (SS), flax seed (FS), and canola seed (CS).

${ }^{2} \mathrm{FA}=$ fatty acid; expressed as $\%$ total fatty acid methyl esters.

tively related to total entodiniomorphs and negatively related to milk $c 15-18: 1$ and $c 11-18: 1$. In the case of the CS diet, however, only DMI and forage DMI were positively related to $\mathrm{CH}_{4}$ and 15:0 tended to be negatively related $(\mathrm{r}=0.65 ; P=0.08)$ to $\mathrm{CH}_{4}$.

\section{Regression Analysis}

Stepwise regression analysis done with each group of test variables using data from all diets is presented in Table 7 . The best equation resulted when all of the test variables (intake, milk FA, and rumen fermentation variables) were included in the model. According to this equation (equation 5 in Table 7), milk $c 9-17: 1$, 16:0 iso and total entodiniomorphs contributed 64, 18, and $8 \%$ of the variability in enteric $\mathrm{CH}_{4}\left(\mathrm{R}^{2}=0.90\right.$; $\mathrm{n}=16 ; P<0.0001)$. A reasonably good prediction equation resulted with the inclusion of milk FA and intake parameters (equation 4 in Table $7 ; \mathrm{R}^{2}=0.83 ; \mathrm{n}$ $=32$ ). Variables that contributed to $\mathrm{CH}_{4}$ were $c 9-17: 1$ $(42 \%), c 11-18: 1$ (14\%), $t, t$-CLA (7\%), total $t-18: 1(6 \%)$, 15:0 anteiso (5\%), 17:0 (5\%), and DMI (6\%). Milk FA alone predicted $75 \%$ of the variability in $\mathrm{CH}_{4}$, with the major contributors being $c 9-17: 1$ (42\%) and $c 11-18: 1$
(14\%; equation 3 in Table 7). When only intake and production variables were included in the model, DMI, milk yield, and intake of SFA predicted 27, 15, and $16 \%$ of the variability in $\mathrm{CH}_{4}$ (equation 2 in Table 7). The simplest equation resulted with the model containing only the rumen variable acetate:propionate ratio explaining $44 \%$ of the variability in enteric $\mathrm{CH}_{4}$ (equation 1 in Table 7). Repeating the regression analysis within diets revealed that coefficient of determination values were greater and standard error values lower (Table 8). However, the variables contributing to $\mathrm{CH}_{4}$ were not all the same from one diet to another.

\section{Enteric $\mathrm{CH}_{4}$ Predicted from Equations Reported in Previous Studies}

Enteric $\mathrm{CH}_{4}(\mathrm{~g} / \mathrm{d})$ estimated using equation 1 and 2 reported by Chilliard et al. (2009) resulted in overprediction of $\mathrm{CH}_{4}$ (Table 9). The average percentage over-prediction for the FS, SS, CS, and CTL diets was $12,14,20$, and $41 \%$, respectively, for equation 2 , and $54,64,48$, and $79 \%$, respectively, for equation 1. Enteric $\mathrm{CH}_{4}$ per kilogram of DM $(\mathrm{g} / \mathrm{d})$, predicted using the equation reported by Dijkstra et al. (2011), also re- 
Table 4. Effect of diets ${ }^{1}$ on milk monounsaturated fatty acids (MUFA), polyunsaturated fatty acids (PUFA), conjugated linoleic acid (CLA) isomers, and desaturase indices

\begin{tabular}{|c|c|c|c|c|c|c|}
\hline \multirow[b]{2}{*}{ Variable $^{2}$} & \multicolumn{4}{|c|}{ Diet } & \multirow[b]{2}{*}{ SEM } & \multirow[b]{2}{*}{$P$-value } \\
\hline & CTL & SS & FS & CS & & \\
\hline$c 9-14: 1$ & 0.92 & 0.91 & 0.90 & 0.94 & 0.07 & NS \\
\hline t9-16:1 & 0.19 & 0.23 & 0.25 & 0.20 & 0.02 & NS \\
\hline$c 9-16: 1$ & $1.87^{\mathrm{a}}$ & $1.18^{\mathrm{b}}$ & $1.20^{\mathrm{b}}$ & $1.11^{\mathrm{b}}$ & 0.10 & $<0.01$ \\
\hline$c 9-17: 1$ & 0.13 & 0.14 & 0.15 & 0.12 & 0.01 & NS \\
\hline$t 6 / t 8-18: 1$ & 0.24 & 0.22 & 0.14 & 0.23 & 0.03 & 0.06 \\
\hline t9-18:1 & 0.33 & 0.39 & 0.30 & 0.36 & 0.03 & 0.07 \\
\hline$t 10-18: 1$ & $0.91^{\mathrm{b}}$ & $1.47^{\mathrm{a}}$ & $1.03^{\mathrm{b}}$ & $0.91^{\mathrm{b}}$ & 0.16 & $<0.01$ \\
\hline$t 11-18: 1$ & $0.84^{\mathrm{b}}$ & $1.69^{\mathrm{a}}$ & $1.07^{\mathrm{b}}$ & $0.92^{\mathrm{b}}$ & 0.14 & $<0.01$ \\
\hline$t 12-18: 1$ & $0.31^{\mathrm{b}}$ & $0.49^{\mathrm{a}}$ & $0.43^{\mathrm{a}}$ & $0.36^{\mathrm{b}}$ & 0.03 & $<0.01$ \\
\hline$t 13 t 14 / c 6-8$ & $0.82^{\mathrm{b}}$ & $0.92^{\mathrm{b}}$ & $1.36^{\mathrm{a}}$ & $0.80^{\mathrm{bc}}$ & 0.10 & $<0.01$ \\
\hline$c 9 / c 10 / t 15-18: 1$ & $22.61^{\mathrm{c}}$ & $28.02^{\mathrm{a}}$ & $26.62^{\mathrm{b}}$ & $28.04^{\mathrm{a}}$ & 0.77 & $<0.01$ \\
\hline$c 11-18: 1$ & $0.63^{\mathrm{b}}$ & $0.68^{\mathrm{b}}$ & $0.65^{\mathrm{b}}$ & $0.78^{\mathrm{a}}$ & 0.05 & $<0.01$ \\
\hline$c 12-18: 1$ & $0.20^{\mathrm{c}}$ & $0.43^{\mathrm{a}}$ & $0.32^{\mathrm{b}}$ & $0.18^{\mathrm{c}}$ & 0.02 & $<0.01$ \\
\hline$c 13-18: 1$ & $0.06^{\mathrm{a}}$ & $0.04^{\mathrm{b}}$ & $0.06^{\mathrm{a}}$ & $0.05^{\mathrm{ab}}$ & 0.01 & 0.01 \\
\hline$c 14 / t 16-18: 1$ & $0.20^{\mathrm{c}}$ & $0.36^{\mathrm{b}}$ & $0.69^{\mathrm{a}}$ & $0.29^{\mathrm{b}}$ & 0.03 & $<0.01$ \\
\hline$c 15-18: 1 / 19: 0$ & $0.11^{\mathrm{b}}$ & $0.10^{\mathrm{b}}$ & $0.49^{\mathrm{a}}$ & $0.14^{\mathrm{b}}$ & 0.04 & $<0.01$ \\
\hline$c 16-18: 1$ & $0.06^{\mathrm{b}}$ & $0.07^{\mathrm{b}}$ & $0.13^{\mathrm{a}}$ & $0.06^{\mathrm{b}}$ & 0.01 & $<0.01$ \\
\hline$\sum t-161$ & 0.58 & 0.59 & 0.57 & 0.56 & 0.03 & NS \\
\hline$\Sigma c-161$ & $1.92^{\mathrm{a}}$ & $1.23^{\mathrm{b}}$ & $1.24^{\mathrm{b}}$ & $1.16^{\mathrm{b}}$ & 0.10 & $<0.01$ \\
\hline$\sum t-181$ & $3.49^{\mathrm{bc}}$ & $5.20^{\mathrm{a}}$ & $4.36^{\mathrm{ab}}$ & $3.62^{\mathrm{b}}$ & 0.41 & $<0.01$ \\
\hline$\Sigma c-181$ & $23.87^{\mathrm{b}}$ & $29.71^{\mathrm{a}}$ & $28.97^{\mathrm{a}}$ & $29.53^{\mathrm{a}}$ & 0.81 & $<0.01$ \\
\hline$\Sigma t$-MUFA & $4.08^{\mathrm{b}}$ & $5.80^{\mathrm{a}}$ & $4.94^{\mathrm{ab}}$ & $4.20^{\mathrm{b}}$ & 0.42 & $<0.01$ \\
\hline$\Sigma c$-MUFA & $27.01^{\mathrm{b}}$ & $32.16^{\mathrm{a}}$ & $31.42^{\mathrm{a}}$ & $32.05^{\mathrm{a}}$ & 0.81 & $<0.01$ \\
\hline$\Sigma$ MUFA & $31.09^{\mathrm{c}}$ & $37.96^{\mathrm{a}}$ & $36.36^{\mathrm{ab}}$ & $36.25^{\mathrm{b}}$ & 0.98 & $<0.01$ \\
\hline$t 9 t 12-18: 2$ & 0.01 & 0.01 & 0.01 & 0.01 & 0.00 & NS \\
\hline$c 9 t 12-18: 2$ & $0.11^{\mathrm{b}}$ & $0.14^{\mathrm{b}}$ & $0.28^{\mathrm{a}}$ & $0.12^{\mathrm{b}}$ & 0.02 & $<0.01$ \\
\hline$c 9, t 13 / t 8, c 12-18: 2$ & $0.21^{\mathrm{b}}$ & $0.29^{\mathrm{b}}$ & $0.59^{\mathrm{a}}$ & $0.25^{\mathrm{b}}$ & 0.05 & $<0.01$ \\
\hline$t 8, c 13-18: 2$ & $0.03^{\mathrm{c}}$ & $0.05^{\mathrm{a}}$ & $0.04^{\mathrm{b}}$ & $0.03^{\mathrm{bc}}$ & 0.00 & $<0.01$ \\
\hline$t 11, c 15-18: 2$ & $0.08^{\mathrm{bc}}$ & $0.06^{\mathrm{bc}}$ & $0.38^{\mathrm{a}}$ & $0.10^{\mathrm{b}}$ & 0.03 & $<0.01$ \\
\hline$c 9 t 11-\mathrm{CLA}$ & $0.51^{\mathrm{c}}$ & $0.97^{\mathrm{a}}$ & $0.68^{\mathrm{b}}$ & $0.61^{\mathrm{bc}}$ & 0.07 & $<0.01$ \\
\hline$t 10 c 12$-CLA & 0.02 & 0.02 & 0.02 & 0.02 & 0.00 & NS \\
\hline $18: 2 \mathrm{n}-6$ & $2.15^{\mathrm{c}}$ & $2.82^{\mathrm{a}}$ & $2.42^{\mathrm{b}}$ & $2.14^{\mathrm{c}}$ & 0.11 & $<0.01$ \\
\hline $18: 3 n-6$ & $0.03^{\mathrm{a}}$ & $0.03^{\mathrm{a}}$ & $0.01^{\mathrm{b}}$ & $0.02^{\mathrm{a}}$ & 0.00 & $<0.01$ \\
\hline $18: 3 n-3$ & $0.19^{\mathrm{c}}$ & $0.18^{\mathrm{c}}$ & $1.01^{\mathrm{a}}$ & $0.30^{\mathrm{b}}$ & 0.04 & $<0.01$ \\
\hline $20: 2 \mathrm{n}-6$ & 0.02 & 0.02 & 0.02 & 0.02 & 0.00 & NS \\
\hline $20: 4 n-6$ & $0.09^{\mathrm{b}}$ & $0.11^{\mathrm{a}}$ & $0.10^{\mathrm{ab}}$ & $0.11^{\mathrm{a}}$ & 0.01 & 0.01 \\
\hline $22: 2 \mathrm{n}-6$ & 0.01 & 0.01 & 0.01 & 0.01 & 0.00 & 0.08 \\
\hline $22: 4 n-3$ & 0.04 & 0.03 & 0.03 & 0.03 & 0.01 & NS \\
\hline DPA & $0.03^{\mathrm{b}}$ & $0.03^{\mathrm{b}}$ & $0.05^{\mathrm{a}}$ & $0.04^{\mathrm{ab}}$ & 0.00 & 0.01 \\
\hline DHA & 0.00 & 0.00 & 0.01 & 0.00 & 0.00 & NS \\
\hline$\Sigma$ n-3 PUFA & $0.27^{\mathrm{c}}$ & $0.25^{\mathrm{c}}$ & $1.11^{\mathrm{a}}$ & $0.38^{\mathrm{b}}$ & 0.04 & $<0.01$ \\
\hline$\Sigma$ n-6 PUFA & $2.41^{\mathrm{c}}$ & $3.11^{\mathrm{a}}$ & $2.65^{\mathrm{b}}$ & $2.42^{\mathrm{c}}$ & 0.11 & $<0.01$ \\
\hline$\Sigma$ PUFA & $2.68^{\mathrm{c}}$ & $3.35^{\mathrm{b}}$ & $3.76^{\mathrm{a}}$ & $2.80^{c}$ & 0.14 & $<0.01$ \\
\hline RA yield, $\mathrm{g} / \mathrm{d}$ & $4.24^{\mathrm{b}}$ & $7.41^{\mathrm{a}}$ & $5.30^{\mathrm{b}}$ & $4.99^{\mathrm{b}}$ & 0.65 & $<0.01$ \\
\hline$c 9-14: 1 / 14: 0$ & 0.11 & 0.11 & 0.10 & 0.10 & 0.01 & NS \\
\hline$c 9-16: 1 / 16: 0$ & 0.05 & 0.05 & 0.05 & 0.05 & 0.00 & NS \\
\hline$c 9-18: 1 / 18: 0$ & $2.71^{\mathrm{a}}$ & $2.03^{\mathrm{b}}$ & $2.03^{\mathrm{b}}$ & $2.04^{\mathrm{b}}$ & 0.11 & $<0.01$ \\
\hline $\mathrm{RA} / t 11-18: 1$ & 0.71 & 0.65 & 0.78 & 0.74 & 0.06 & NS \\
\hline
\end{tabular}

${ }^{a-c}$ Within a row, means bearing different superscript letters are different $(P<0.05)$.

${ }^{1}$ Diets were control [CTL; calcium salts of long-chain fatty acids (palm oil)], sunflower seed (SS), flax seed (FS), and canola seed (CS).

${ }^{2} c=c i s ; t=$ trans; DPA $=$ docosapentaenoic acid; DHA $=$ docosahexaenoic acid; RA $=$ rumenic acid $(c 9, t 11$ 18:2); expressed as \% of total fatty acid methyl esters.

sulted in over-prediction (equation 3 in Table $9 ; 34.5 \%$ for FS; $2 \%$ for SS; $26 \%$ for CS; and $15 \%$ for CTL).

\section{DISCUSSION}

Greater concentrations of milk SFA for the CTL diet compared with the SS, FS, and CS diets (Table
3 ) could be attributed mainly to the greater intakes of 16:0 for the CTL diet than for the SS, FS and CS diets (Table 2). Consistent with this observation, milk 16:0 was also greater for the CTL diet than the SS, FS and CS diets (Table 3). Greater concentrations of LeA in milk for the SS diet (Table 4) was consistent with the greater intakes of LeA for the SS diet (Table 2). 
Table 5. Correlations between average methane $(\mathrm{g} / \mathrm{d})$ and milk fatty acid concentrations (\% total fatty acid methyl esters) or rumen parameters $(\mathrm{mol} / 100 \mathrm{~mol})$ or intake parameters $(\mathrm{kg} / \mathrm{d})$ in cows supplemented with various sources of long-chain fatty acids ${ }^{1}$

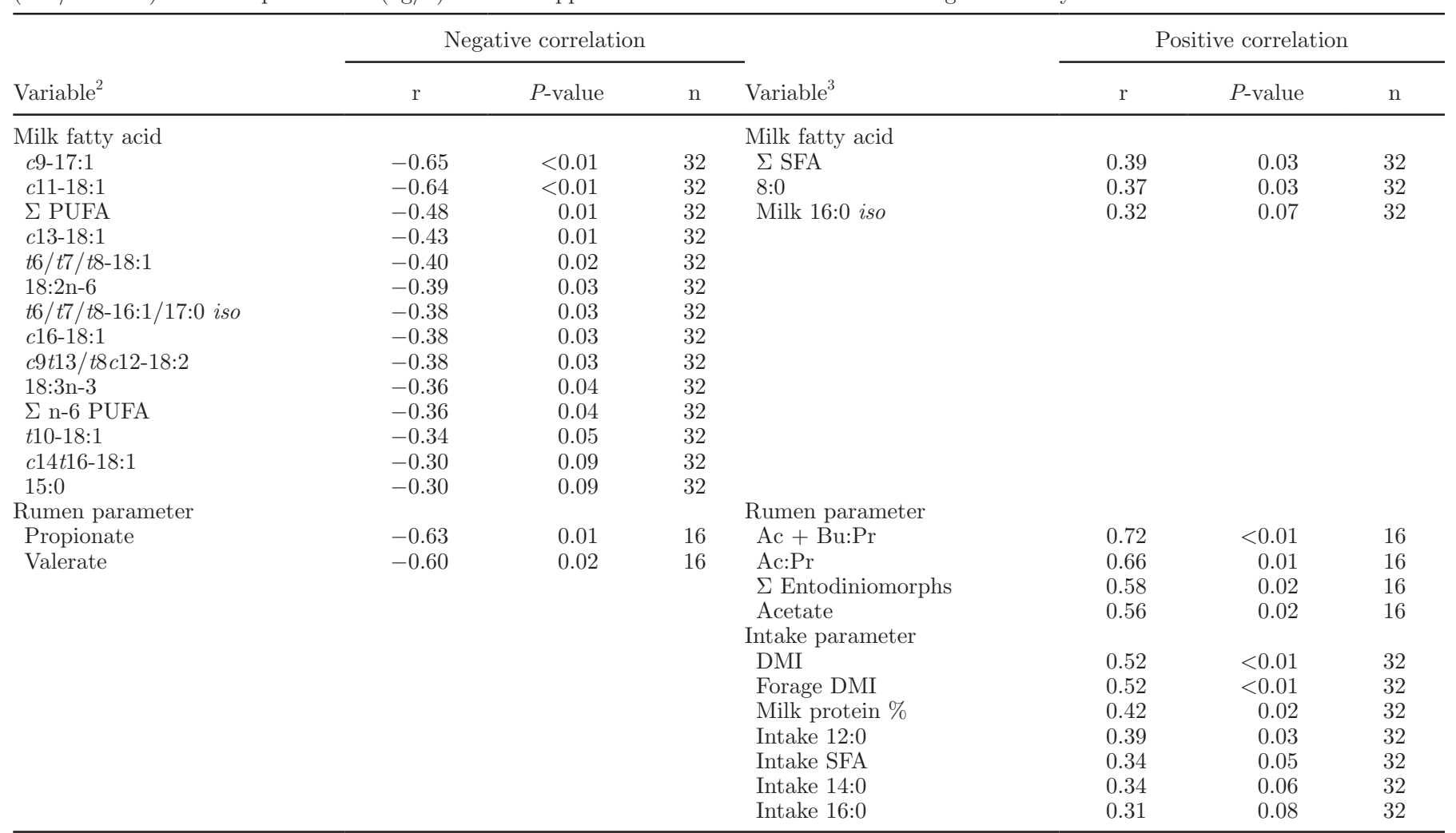

${ }^{1}$ Diets were control [calcium salts of long-chain fatty acids (palm oil)], sunflower seed, flax seed, and canola seed.

${ }^{2} c=$ cis; $t=$ trans; PUFA $=$ polyunsaturated fatty acids.

${ }^{3} \mathrm{SFA}=$ saturated fatty acids; $\mathrm{Ac}=$ acetate; $\mathrm{Bu}=$ butyrate; $\mathrm{Pr}=$ propionate.

Similarly, greater milk LN for the FS diet (Table 4) was consistent with greater intakes of LN for the FS diet (Table 2). Greater polyunsaturated FA (PUFA) intake often results in inhibition of biohydrogenation efficiency (Harfoot et al., 1973; Beam et al., 2000). Greater milk 18:0 for the CS, FS, and SS diets compared with the CTL diet was consistent with the greater PUFA intakes for these diets. To evaluate biohydrogenation efficiency, milk 18:0 per gram of LeA + LN intake was determined $(\mathrm{CTL}=0.06 \%$; $\mathrm{SS}=0.02 \%$; $\mathrm{FS}=0.02 \%$; and $\mathrm{CS}=0.02 \%)$. The greater values of milk 18:0 per gram of LeA + LN intake for the CTL diet than for the SS, FS, and CS diets suggest that the CTL diet was less inhibitory to biohydrogenation compared with the other diets.

Greater $t 11-18: 1$ for the SS diet compared with the FS diet was anticipated based on previous studies in which diets supplemented with a lipid source rich in LeA resulted in greater t11-18:1 compared with a lipid source rich in LN (Bell et al., 2006; Bu et al., 2007). However, a lack of difference in t11-18:1 between the CTL diet and FS or CS diets was surprising. As expected, milk t10-18:1 was greater for the SS diet compared with the other diets. Several studies demonstrated that diets rich in SS or oil invariably cause a shift to $t 10-18: 1$ (Bell et al., 2006; Shingfield et al., 2006; Mohammed et al., 2011). Greater milk CLA for the SS diet compared with the other diets could be attributed to the greater proportion of $t 11-18: 1$ for the SS diet than for the CS, FS, and CTL diets. It should be noted that despite the greater intake of total PUFA substrate $(\mathrm{LeA}+\mathrm{LN})$ for the FS diet, milk CLA was greater for the SS diet and not for the FS diet, reflecting greater efficiency of SS in increasing milk CLA. This observation is supported by the greater RA yield for the SS diet compared with the other diets.

\section{Relationship Between $\mathrm{CH}_{4}$ and Test Variables}

It should be noted that the observed relationships between $\mathrm{CH}_{4}$ production and test variables does not imply a cause and effect relationship. However, a strong and consistent relationship between a test variable and $\mathrm{CH}_{4}$ production would be suspected of having some biological relevance. One of our objectives was to model the relationship between $\mathrm{CH}_{4}$ and various test variables 
Table 6. Treatment-wise correlations between average methane $(\mathrm{g} / \mathrm{d})$ and milk fatty acid concentrations (\% total fatty acid methyl esters), rumen parameters $(\mathrm{mol} / 100 \mathrm{~mol})$, or intake parameters $(\mathrm{kg} / \mathrm{d})$ in cows supplemented with various sources of long-chain fatty acids ${ }^{1}$

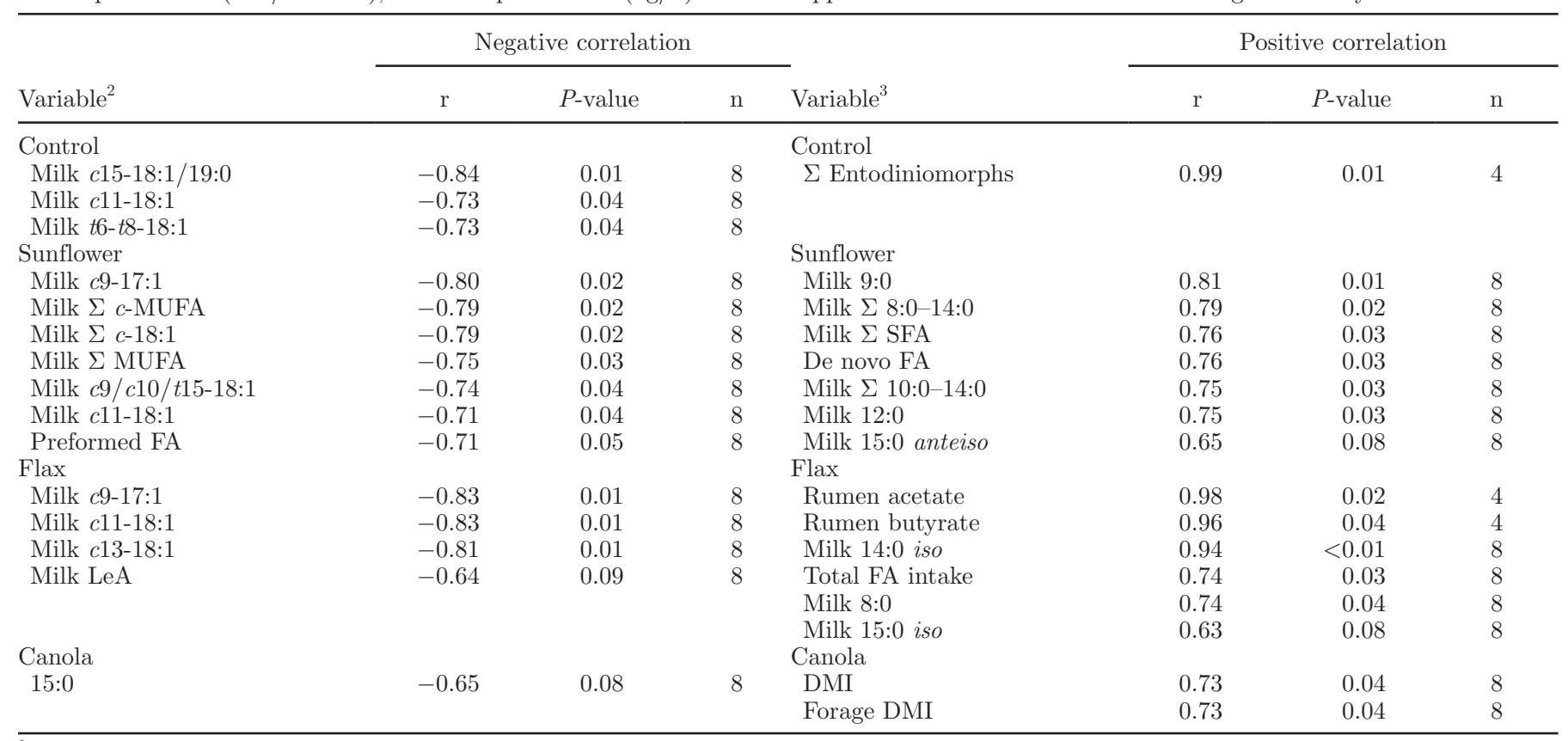

${ }^{1}$ Diets were control [calcium salts of long-chain fatty acids (palm oil)], sunflower seed, flax seed, and canola seed.

${ }^{2} c=c i s ; t=$ trans; MUFA $=$ monounsaturated fatty acids; $\mathrm{FA}=$ fatty acid; LeA $=$ linoleic acid.

${ }^{3} \mathrm{SFA}=$ saturated fatty acids.

to determine if it would be possible to predict $\mathrm{CH}_{4}$ with reasonable accuracy.

Correlations between $\mathrm{CH}_{4}$ and the test variables were stronger within diet (Table 6) compared with those obtained with all diets (Table 5) in the model. This finding is consistent with the strong correlations observed in the study of Chilliard et al. (2009), wherein diets used were not very diverse and differed only in the physical form of linseed supplemented. Lower correlation coefficient values observed when all diets were included in the model (Table 5) reflect the weakness of the model in predicting $\mathrm{CH}_{4}$ for diverse diets. Similarly, Dijkstra et al. (2011) reported relatively weaker correlations between $\mathrm{CH}_{4}$ and milk $\mathrm{FA}$ in a meta-analysis of data from 3 different experiments.

It is well known that $\mathrm{CH}_{4}$ output is proportional to DMI (Giger-Reverdin et al., 2003; Grainger et al., 2007). Consistent with this, total DMI and forage DMI were positively related to $\mathrm{CH}_{4}$ (Table 5). Supplementing diets with oilseeds rich in unsaturated FA has been recommended as a strategy for inhibiting $\mathrm{CH}_{4}$ emissions (Boadi et al., 2004; Beauchemin et al., 2007). It was anticipated that intake of oleic acid, LeA, LN, or LeA + LN would, therefore, be negatively related to $\mathrm{CH}_{4}$ production. However, none of these FA was related to $\mathrm{CH}_{4}$ production, indicating that the $\mathrm{CH}_{4}$-suppressing effects observed with the supplementation of oilseeds is not due to the direct action of the unsaturated FA but possibly due to the intermediary metabolic products resulting from the biohydrogenation of these FA in the rumen. This effect is supported by the negative correlations observed between $\mathrm{CH}_{4}$ and the isomers of 18:1 and 18:2 in milk, which is consistent with the findings of Chilliard et al. (2009; Table 5).

Negative correlations of $\mathrm{CH}_{4}$ with rumen propionate and positive correlations with acetate, acetate:propionate, and the ratio acetate + butyrate:propionate (Table 5) are consistent with the stoichiometric relationship $\mathrm{CH}_{4}=0.45$ acetate -0.275 propionate +0.40 butyrate (Demeyer and Van Nevel, 1975; Moss et al., 2000). The conversion of pyruvate to acetate in the rumen results in the formation of $\mathrm{H}$, whereas the conversion of pyruvate to propionate involves utilization of $\mathrm{H}$ (Moss et al., 2000). This fermentation pathway explains the positive and negative correlations of acetate and propionate, respectively, with $\mathrm{CH}_{4}$. The positive correlations observed between $\mathrm{CH}_{4}$ production and total entodiniomorphs could be explained by the symbiotic relationship between methanogens and protozoa (Vogels et al., 1980; Finlay et al., 1994). As much as 37\% of methanogenesis in the rumen is estimated to be contributed by methanogens associated with protozoa (Finlay et al., 1994). The strong positive correlation between $\mathrm{CH}_{4}$ production and total entodiniomorphs for the CTL 
Table 7. Stepwise regression analysis of various parameters with methane $\left(\mathrm{CH}_{4}\right)$ output using data from all diets ${ }^{1}$

\begin{tabular}{|c|c|c|c|c|}
\hline Variable $^{2}$ & Partial $\mathrm{R}^{2}$ & Model $\mathrm{R}^{2}$ & $F$-value & $P$-value \\
\hline Acetate:propionate (a), mol/100 mol & 0.44 & 0.44 & 10.92 & 0.01 \\
\hline Equation 1 & \multicolumn{4}{|c|}{$\mathrm{CH}_{4}(\mathrm{~g} / \mathrm{d})=75.34 \mathrm{a}( \pm 22.8)+59.41( \pm 58.2)$} \\
\hline $\operatorname{DMI}(\mathrm{a}), \mathrm{kg} / \mathrm{d}$ & 0.27 & 0.27 & 11.09 & $<0.01$ \\
\hline Milk yield (b), kg/d & 0.15 & 0.42 & 7.54 & 0.01 \\
\hline Intake of SFA (c), g/d & 0.16 & 0.58 & 10.68 & $<0.01$ \\
\hline With milk fatty acid concentrations ( $\%$ FAME) $(\mathrm{n}=32 ; P<0.0001)$ & & & & \\
\hline$c 9-17: 1$ (a) & 0.42 & 0.42 & 21.45 & $<0.01$ \\
\hline$c 11-18: 1(\mathrm{~b})$ & 0.14 & 0.56 & 9.08 & 0.01 \\
\hline$t, t$-CLA (c) & 0.07 & 0.63 & 5.67 & 0.02 \\
\hline$\sum t-18: 1(\mathrm{~d})$ & 0.06 & 0.69 & 5.71 & 0.02 \\
\hline 15:0 anteiso (e) & 0.05 & 0.74 & 5.27 & 0.03 \\
\hline Equation 3 & \multicolumn{4}{|c|}{$\begin{array}{c}\mathrm{CH}_{4}(\mathrm{~g} / \mathrm{d})=-486.2 \mathrm{a}( \pm 191.8)-122.7 \mathrm{~b}( \pm 44.12)+2,220 \mathrm{c} \\
( \pm 515.6)-11.76 \mathrm{~d}( \pm 4.66)+260.1 \mathrm{e}( \pm 113.3)+272.4( \pm 67.8)\end{array}$} \\
\hline \multicolumn{5}{|l|}{$\begin{array}{l}\text { With milk fatty acids (\% FAME), intake and production } \\
\text { parameters }(\mathrm{kg} / \mathrm{d})(\mathrm{n}=32: P<0.0001)\end{array}$} \\
\hline$t, t-\mathrm{CLA}(\mathrm{c})$ & 0.07 & 0.63 & 5.67 & 0.02 \\
\hline$\sum t-18: 1(\mathrm{~d})$ & 0.06 & 0.69 & 5.71 & 0.02 \\
\hline 15:0 anteiso (e) & 0.05 & 0.74 & 5.27 & 0.03 \\
\hline $17: 0(\mathrm{f})$ & 0.05 & 0.79 & 5.89 & 0.02 \\
\hline c9-17:1 (removed) & 0.02 & 0.77 & 2.24 & 0.15 \\
\hline DMI $(g)$ & 0.06 & 0.83 & 9.57 & $<0.01$ \\
\hline Equation 4 & \multicolumn{4}{|c|}{$\begin{array}{l}\mathrm{CH}_{4}(\mathrm{~g} / \mathrm{d})=-124.9 \mathrm{~b}( \pm 33.66)+2,115.9 \mathrm{c}( \pm 432.6)-10.04 \mathrm{~d}( \pm 3.84) \\
+455.5 \mathrm{e}( \pm 98.9)-305.9 \mathrm{f}( \pm 80.7)+7.83 \mathrm{~g}( \pm 2.53)+104.8( \pm 61.9)\end{array}$} \\
\hline \multicolumn{5}{|l|}{$\begin{array}{l}\text { With milk fatty acids ( } \% \text { FAME), intake, production } \\
\text { and rumen parameters }(\mathrm{n}=16 ; P<0.0001)\end{array}$} \\
\hline$c 9-17: 1(\mathrm{a})$ & 0.64 & 0.64 & 25.13 & $<0.01$ \\
\hline $16: 0$ iso $(\mathrm{b})$ & 0.18 & 0.82 & 13.23 & $<0.01$ \\
\hline$\Sigma$ Entodiniomorphs (c) & 0.08 & 0.90 & 10.36 & 0.01 \\
\hline Equation 5 & \multicolumn{4}{|c|}{$\begin{array}{c}\mathrm{CH}_{4}(\mathrm{~g} / \mathrm{d})=-910.8 \mathrm{a}( \pm 156.7)+331.2 \mathrm{~b}( \pm 88.8) \\
+0.0001 \mathrm{c}( \pm 0.00)+242.5( \pm 39.7)\end{array}$} \\
\hline
\end{tabular}

${ }^{1}$ Diets were control [calcium salts of long-chain fatty acids (palm oil)], sunflower seed, flax seed, and canola seed.

${ }^{2} c=$ cis $;=$ trans SFA $=$ saturated fatty acids; FAME $=$ fatty acid methyl esters; CLA $=$ conjugated linoleic acid.

diet is consistent with the greater $\mathrm{CH}_{4}$ emissions and total protozoa observed for the CTL diet compared with the other diets (Beauchemin et al., 2009).

The best equation in this study predicted $\mathrm{CH}_{4}$ with the variables milk $c 9-17: 1$ and 16:0 iso and total entodiniomorphs. It is well known that milk 17:0 has microbial origin and c9-17:1 is a production of desaturation of 17:0 by the mammary desaturase system (Fievez et al., 2003). However, the biological relevance of 17:0 in connection with methanogenesis is not known and is worth exploring. The role of 16:0 iso in relation to methanogenesis is not known except that it has microbial origin. Prediction of $\mathrm{CH}_{4}$ with only milk FA and intake variables also resulted in $c 9-17: 1$ being the major contributor, followed by $c 11-18: 1 ; t, t$-CLA; total $t-18: 1$; 15:0 anteiso; 17:0; and DMI. Variables in this equation were only partly similar to the equations reported in previous studies (c11-18:1; Dijkstra et al., 2011). The major contributors predicting $\mathrm{CH}_{4}(\mathrm{~g} / \mathrm{kg}$ of DM) in the study of Dijkstra et al. (2011) were 17:0 anteiso, fol- lowed by $t 10+t 11-18: 1 ; c 11-18: 1 ;$ and $c 13-18: 1$ and those in the study of Chilliard et al. (2009) were milk 14c/16t-18:1, 16:0, and forage intake. The lack of similarity in the equations could be due to differences in the diets as well as analytical procedures among the studies. Even the prediction equation developed for the FS diet in the current study was different from the equations for linseed-supplemented diets reported by Chilliard et al. (2009). Diets used in their study were corn silage based (unlike barley silage in the present study) and contained a greater mean proportion of forage (63 vs. $45 \%)$ than in the current study. Differences in the equations could, therefore, be due to differences in the basal diet and proportion of forages between the studies. In the current study, forage DMI was included in the model for stepwise regression analyses. However, it did not contribute to the variability in $\mathrm{CH}_{4}$, unlike in the study of Chilliard et al. (2009). The lack of contribution of forage DMI to $\mathrm{CH}_{4}$ in this study could be because forage DMI was estimated from TMR DMI 
Table 8. Stepwise regression analysis of milk fatty acids, intake, and production parameters with methane output using data from each diet ${ }^{1}$

\begin{tabular}{|c|c|c|c|c|}
\hline Variable $^{2}$ & Partial $R^{2}$ & Model $\mathrm{R}^{2}$ & $F$-value & $P$-value \\
\hline \multicolumn{5}{|l|}{ Control (n $=8 ; P=0.0004)$} \\
\hline$c 15-18: 1$ (a) & 0.71 & 0.71 & 14.57 & 0.01 \\
\hline$t 10, c 12$-CLA (b) & 0.25 & 0.96 & 33.09 & $<0.01$ \\
\hline$c 9-20: 1(\mathrm{~d})$ & 0.0060 & 0.997 & 12.38 & 0.04 \\
\hline$\Sigma$ fatty acid intake (e) & 0.0020 & 0.999 & 18.64 & 0.04 \\
\hline $10: 0(\mathrm{f})$ & 0.0001 & 1.000 & $9,547.95$ & 0.01 \\
\hline Equation & \multicolumn{4}{|c|}{$\begin{array}{l}\mathrm{CH}_{4}(\mathrm{~g} / \mathrm{d})=-3,798.2 \mathrm{a}( \pm 0.65)-3,927.4 \mathrm{~b}( \pm 1.46)-79.7 \mathrm{c}( \pm 0.11) \\
+116.3 \mathrm{~d}( \pm 0.28)-0.02 \mathrm{e}( \pm 0.00)-4.67 \mathrm{f}( \pm 0.05)+806.2( \pm 0.16)\end{array}$} \\
\hline \multicolumn{5}{|c|}{$+110.0 \mathrm{~d}( \pm 0.20)-0.02 \mathrm{e}( \pm 0.00)-4.011( \pm 0.00)+800.2( \pm 0.10)$} \\
\hline$c 9-17: 1(\mathrm{a})$ & 0.65 & 0.65 & 11.04 & 0.01 \\
\hline$c 14 / t 16-18: 1(\mathrm{~b})$ & 0.28 & 0.93 & 19.26 & 0.01 \\
\hline $\mathrm{DMI}(\mathrm{c})$ & 0.06 & 0.99 & 24.86 & 0.01 \\
\hline $13: 0$ (d) & 0.009 & 0.999 & 81.13 & $<0.01$ \\
\hline$t, t$ diene $(\mathrm{e})$ & 0.001 & 1.000 & 384.5 & $<0.01$ \\
\hline Equation & \multicolumn{4}{|c|}{$\begin{array}{c}\mathrm{CH}_{4}(\mathrm{~g} / \mathrm{d})=-1,587.5 \mathrm{a}( \pm 0.03)-696.9 \mathrm{~b}( \pm 0.02)-7.34 \mathrm{c}( \pm 0.00) \\
-210.2 \mathrm{~d}( \pm 0.06)+76.5 \mathrm{e}( \pm 0.15)+881.9( \pm 0.02)\end{array}$} \\
\hline $9: 0(\mathrm{~d})$ & 0.012 & 0.999 & 88.29 & $<0.01$ \\
\hline$c 11-18: 1$ (e) & 0.001 & 1.000 & 87.20 & 0.01 \\
\hline Equation & \multicolumn{4}{|c|}{$\begin{array}{c}\mathrm{CH}_{4}(\mathrm{~g} / \mathrm{d})=0.86 \mathrm{a}( \pm 0.00)-247.6 \mathrm{~b}( \pm 0.00)-283.5 \mathrm{c}( \pm 0.01) \\
+155.7 \mathrm{~d}( \pm 0.01)-13.83 \mathrm{e}( \pm 0.00)+278.2( \pm 0.01)\end{array}$} \\
\hline \multicolumn{5}{|l|}{ Canola $(\mathrm{n}=8 ; P<0.0001)$} \\
\hline DMI (a) & 0.54 & 0.54 & 6.93 & 0.04 \\
\hline$\Sigma$ n-3 PUFA (b) & 0.34 & 0.88 & 13.88 & 0.01 \\
\hline$c 11-20: 1$ (c) & 0.09 & 0.97 & 13.69 & 0.02 \\
\hline Intake of LN (d) & 0.02 & 0.99 & 11.45 & 0.04 \\
\hline 13:0 anteiso (e) & 0.01 & 1.00 & 983.01 & $<0.01$ \\
\hline Equation & \multicolumn{4}{|c|}{$\begin{array}{c}\mathrm{CH}_{4}(\mathrm{~g} / \mathrm{d})=35.5 \mathrm{a}( \pm 0.10)+634.9 \mathrm{~b}( \pm 2.85)-783.2 \mathrm{c}( \pm 7.07) \\
-0.43 \mathrm{~d}( \pm 0.01)-564.1 \mathrm{e}( \pm 18.0)-530.5( \pm 2.28)\end{array}$} \\
\hline
\end{tabular}

${ }^{1}$ Diets were control [calcium salts of long-chain fatty acids (palm oil)], sunflower seed, flax seed, and canola seed.

${ }^{2} c=c i s ; t=$ trans; CLA $=$ conjugated linoleic acid; LN = linolenic acid; PUFA = polyunsaturated fatty acids.

Table 9. Prediction of methane $\left(\mathrm{CH}_{4}\right)$ output from equations reported in the literature

\begin{tabular}{|c|c|c|c|}
\hline $\operatorname{Diet}^{1}$ & $\begin{array}{c}\text { Mean } \\
\text { predicted } \mathrm{CH}_{4}\end{array}$ & $\begin{array}{c}\text { Mean } \\
\text { actual } \mathrm{CH}_{4}\end{array}$ & $\begin{array}{c}\% \text { over } \\
\text { predicted }\end{array}$ \\
\hline \multicolumn{4}{|c|}{ Equation 1 (Chilliard et al., 2009) ${ }^{2}$} \\
\hline CTL & 526.0 & 293.3 & 79.4 \\
\hline SS & 431.8 & 264.0 & 63.6 \\
\hline FS & 369.9 & 240.4 & 53.9 \\
\hline CS & 392.2 & 265.1 & 48.0 \\
\hline \multicolumn{4}{|c|}{ Equation 2 (Chilliard et al., 2009) ${ }^{3}$} \\
\hline CTL & 412.1 & 293.3 & 40.5 \\
\hline SS & 302.1 & 264.0 & 14.4 \\
\hline FS & 269.0 & 240.4 & 11.9 \\
\hline CS & 319.3 & 265.1 & 20.4 \\
\hline \multicolumn{4}{|c|}{ Equation 3 (Dijkstra et al., 2011) } \\
\hline CTL & 18.69 & 16.20 & 15.35 \\
\hline SS & 14.82 & 14.53 & 1.99 \\
\hline FS & 18.01 & 13.39 & 34.50 \\
\hline CS & 17.18 & 13.64 & 25.98 \\
\hline
\end{tabular}

${ }^{1}$ Diets were control [CTL; calcium salts of long-chain fatty acids (palm oil)], sunflower seed (SS), flax seed (FS), and canola seed (CS).

${ }^{2} \mathrm{CH}_{4}$ output $(\mathrm{g} / \mathrm{d})=9.46 \times$ milk 16:0 $(\%$ of total FAME) $-97.6 \times$ milk $t 16, c 14-18: 1+13.3 \times$ forage intake $(\mathrm{kg}$ of $\mathrm{DM} / \mathrm{d})-78.3 \times$ milk $c 9-14: 1+77.4 \times$ milk $18: 2 \mathrm{n}-6-21.2 ; t=$ trans; $c=$ cis; FAME $=$ fatty acid methyl esters.

${ }^{3} \mathrm{CH}_{4}$ output $(\mathrm{g} / \mathrm{d})=-100.8( \pm 22.0) \times$ milk $t 16 / c 14-18: 1(\%$ of total FAME $)+6.78( \pm 1.75) \times$ milk 16:0 $(\%$ of total FAME) $+13.1( \pm 3.86) \times$ forage intake $(\mathrm{kg}$ of DM $/ \mathrm{d})+80.1( \pm 60.9)$.

${ }^{4} \mathrm{CH}_{4}(\mathrm{~g} / \mathrm{kg}$ of DM $)=24.6+8.74 \times 17: 0$ anteiso $(\%$ of total FAME $)-1.97 \times t 10+t 11-18: 1-9.09 \times c 11-18: 1$ $+5.07 \times c 13-18: 1$ 
based on the proportion of forage in the diet, whereas forage DMI in the study of Chilliard et al. (2009) was recorded, as it involved feeding forage and grain separately.

Based on the stoichiometric relationship between $\mathrm{CH}_{4}$ and rumen VFA (Demeyer and Van Nevel, 1975; Moss et al., 2000) and the role of milk OBCFA as markers for predicting rumen fermentation pattern (Vlaeminck et al., 2006), Montoya et al. (2011) reported that milk OBCFA hold potential as predictors of rumen methanogenesis. In the current study, $\mathrm{CH}_{4}$ production was related positively to milk 14:0 iso (FS diet, Table 6) and negatively to $c 9-17: 1$ (Tables 5 and 6 ), consistent with the findings of Montoya et al. (2011). Among the different OBCFA, $c 9-17: 1$ contributed most in the $\mathrm{CH}_{4}$ prediction equations developed in this study.

The best equation described by Chilliard et al. (2009) involved the variables milk 16:0, t16/c14-18:1, forage intake, $c 9-14: 1$, and milk 18:2. Estimating $\mathrm{CH}_{4}$ using both equations 1 and 2 reported by Chilliard et al. (2009) resulted in over-prediction of $\mathrm{CH}_{4}$ (Table 9). This could be attributed to the lack of correlations between $\mathrm{CH}_{4}$ and the variables described above (except for forage DMI and milk 18:2) in the present study. However, it should be noted that equation 2 described by Chilliard et al. (2009) involving only 2 milk FA and forage DMI resulted in lesser over-estimation of $\mathrm{CH}_{4}$ (mean value for all 4 diets 22\%), in contrast to equation 1 involving 4 milk FA and forage DMI (mean value for all 4 diets $61 \%$ ). This result suggests that milk FA variables may be less suitable for predicting methane compared to DMI variables. The $\mathrm{CH}_{4}$ prediction equation developed by Dijkstra et al. (2011) involving the variables 17:0 anteiso, t10- + t11-18:1, c11-18:1, and $c 13-18: 1$ also resulted in over-prediction. This could be attributed to the lack of correlations between $\mathrm{CH}_{4}$ and the variables described above (except the variables $c 11$ and $c 13-18: 1)$ in the current study.

\section{CONCLUSIONS}

A data set from dairy cows fed diets supplemented with oilseeds was used to evaluate the effects of fatsupplemented diets on milk FA profile; model $\mathrm{CH}_{4}$ production from milk FA composition, intake, and rumen fermentation variables; and test the applicability of $\mathrm{CH}_{4}$ prediction equations reported in previous studies. Milk FA composition for cows fed diets supplemented with various sources of long-chain FA revealed that t11-18:1, RA, and RA yield was greater for the SS diet compared with FS, CS, and CTL diets. Methane output $(\mathrm{g} / \mathrm{d})$ was positively related to total DMI $(\mathrm{kg} / \mathrm{d})$, forage DMI $(\mathrm{kg} / \mathrm{d})$, and the ratio ruminal acetate + butyrate:propionate $(\mathrm{mol} / 100 \mathrm{~mol})$ and negatively re- lated to rumen propionate concentration, milk $c 9-17: 1$, and $c 11-18: 1$ (\% of total FAME). The best equation predicted $\mathrm{CH}_{4}$ with a correlation coefficient of 0.90 and included milk $c 9-17: 1,16: 0$ iso, and total entodiniomorphs. Using only milk FA, intake and production variables also provided a good estimate of $\mathrm{CH}_{4}\left(\mathrm{R}^{2}=\right.$ 0.83). More accurate predictions were developed when specific to individual diets, but the data set was limited in size. Previously published equations over-predicted $\mathrm{CH}_{4}$ production by 19 to $61 \%$. Overall, this body of research demonstrates that the scope for developing universal methane prediction equations from milk FA composition alone appears to be limited.

\section{REFERENCES}

Beam, T. M., T. C. Jenkins, P. J. Moate, R. A. Kohn, and D. L. Palmquist. 2000. Effect of amount and source of fat on the rates of lipolysis and biohydrogenation of fatty acids in ruminal contents. J. Dairy Sci. 83:2564-2573.

Beauchemin, K. A., S. M. McGinn, C. Benchaar, and L. Holtshausen. 2009. Crushed sunflower, flax, or canola seeds in lactating dairy cow diets: Effects on methane production, rumen fermentation, and milk production. J. Dairy Sci. 92:2118-2127.

Beauchemin, K. A., S. M. McGinn, and H. V. Petit. 2007. Methane abatement strategies for cattle: Lipid supplementation of diets. Can. J. Anim. Sci. 87:431-440.

Bell, J. A., J. M. Griinari, and J. J. Kennelly. 2006. Effect of safflower oil, flaxseed oil, monensin, and vitamin E on concentrations of conjugated linoleic acid in bovine milk fat. J. Dairy Sci. 89:733-748.

Boadi, D., C. Benchaar, J. Chiquette, and D. Massé. 2004. Mitigation strategies to reduce enteric methane emissions from dairy cows: Update review. Can. J. Anim. Sci. 84:319-335.

Bu, D. P., J. Q. Wang, T. R. Dhiman, and S. J. Liu. 2007. Effectiveness of oils rich in linoleic and linolenic acids to enhance conjugated linoleic acid in milk from dairy cows. J. Dairy Sci. 90:998-1007.

Chilliard, Y., C. Martin, J. Rouel, and M. Doreau. 2009. Milk fatty acids in dairy cows fed whole crude linseed, extruded linseed, or linseed oil, and their relationship with methane output. J. Dairy Sci. 92:5199-5211.

Demeyer, D. I., and C. J. Van Nevel. 1975. Methanogenesis, an integrated part of carbohydrate fermentation and its control. Pages 366-382 in Digestion and Metabolism in the Ruminant. I. W McDonald and A. C. I. Warner, ed. University of New England, Armidale, Australia.

Dijkstra, J., S. M. van Zijderveld, J. A. Apajalahti, A. Bannink, W. J. J. Gerrits, J. R. Newbold, H. B. Perdok, and H. Berends. 2011. Relationships between methane production and milk fatty acid profiles in dairy cattle. Anim. Feed Sci. Technol. 166:590-595.

Fievez, V., B. Vlaeminck, M. S. Dhanoa, and R. J. Dewhurst. 2003. Use of principal component analysis to investigate the origin of heptadecenoic and conjugated linoleic acids in milk. J. Dairy Sci. 86:4047-4053.

Finlay, B. J., G. Esteban, K. J. Clarke, A. G. Williams, T. M. Embley, and R. R. Hirt. 1994. Some rumen ciliates have endosymbiotic methanogens. FEMS Microbiol. Lett. 117:157-161.

Giger-Reverdin, S., P. Morand-Fehr, and G. Tran. 2003. Literature survey of the influence of dietary fat composition on methane production in dairy cattle. Livest. Prod. Sci. 82:73-79.

Grainger, C., T. Clarke, S. M. McGinn, M. J. Auldist, K. A. Beauchemin, M. C. Hannah, G. C. Waghorn, H. Clark, and R. J. Eckard. 2007. Methane emissions from dairy cows measured using the sulfur hexafluoride (SF6) tracer and chamber techniques. J. Dairy Sci. 90:2755-2766.

Harfoot, C. G., R. C. Noble, and J. H. Moore. 1973. Factors influencing the extent of biohydrogenation of linoleic acid by rumen microorganism in vitro. J. Sci. Food Agric. 24:961-970. 
IPCC (International Panel on Climate Change). 2006. Revised IPCC Guidelines for National Greenhouse Gas Inventories. Chapter 10, Vol. 4, Agriculture, forestry and other land use. Accessed Feb. 12, 2011. http://www.ipcc-nggip.iges.or.jp/public/2006gl/vol4.htm.

Johnson, K. A., and D. E. Johnson. 1995. Methane emissions from cattle. J. Anim. Sci. 73:2483-2492.

Kramer, J. K. G., M. Hernandez, C. Cruz-Hernandez, J. Kraft, and M. E. R. Dugan. 2008. Combining results of two GC separations partly achieves determination of all cis and trans 16:1, 18:1, 18:2 and 18:3 except CLA isomers of milk fat as demonstrated using Ag-ion SPE fractionation. Lipids 43:259-273.

Mohammed, R., R. G. Khorasani, L. A. Goonewardene, J. K. G. Kramer, and J. J. Kennelly. 2011. Persistency of milk trans-18:1 isomers and rumenic acid in Holstein cows over a full lactation. Can. J. Anim. Sci. 91:147-167. doi:10.4141/CJAS10059.

Mohammed, R., C. S. Stanton, J. J. Kennelly, J. K. G. Kramer, J. F. Mee, D. R. Glimm, M. O'Donovan, and J. J. Murphy. 2009. Grazing cows are more efficient than zero-grazed and grass silage-fed cows in milk rumenic acid production. J. Dairy Sci. 92:3874-3893.

Montoya, J. C., A. Bhagwat, N. Peiren, S. De Campeneere, B. De Baets, and V. Fievez. 2011. Relationships between odd- and branched-chain fatty acid profiles in milk and calculated enteric methane proportion for lactating dairy cattle. Anim. Feed Sci. Technol. 166:596-602.

Moss, A. R., J. P. Jouany, and J. Newbold. 2000. Methane production by ruminants: Its contribution to global warming. Ann. Zootech. 49:231-253.

Shingfield, K. J., C. K. Reynolds, G. Hervás, J. M. Griinari, A. S. Grandison, and D. E. Beever. 2006. Examination of the persistency of milk fatty acid composition responses to fish oil and sunflower oil in the diet of dairy cows. J. Dairy Sci. 89:714-732.

Vlaeminck, B., V. Fievez, S. Tamminga, R. J. Dewhurst, A. M. van Vuuren, D. De Brabander, and D. Demeyer. 2006. Milk odd and branched-chain fatty acids in relation to the rumen fermentation pattern. J. Dairy Sci. 89:3954-3964.

Vogels, G. D., W. F. Hoppe, and C. K. Stumm. 1980. Association of methanogenic bacteria with rumen ciliates. Appl. Environ. Microbiol. 40:608-612.

Wolff, R. L., C. C. Bayard, and R. J. Fabien. 1995. Evaluation of sequential methods for the determination of butterfat fatty acid composition with emphasis on trans-18:1 acids. Application to the study of seasonal variations in French butters. J. Am. Oil Chem. Soc. $72: 1471-1483$. 